\title{
Penerapan Convolutional Long Short-Term Memory untuk Klasifikasi Teks Berita Bahasa Indonesia
}

\section{(Convolutional Long Short-Term Memory Implementation for Indonesian News Classification)}

\author{
Yudi Widhiyasana ${ }^{1}$, Transmissia Semiawan ${ }^{2}$, Ilham Gibran Achmad Mudzakir ${ }^{3}$, Muhammad Randi Noor ${ }^{4}$
}

\begin{abstract}
Text classification is now a well-studied field, particularly in Natural Language Processing (NLP). The text classification can be carried out using various methods, one of which is deep learning. Deep learning methods such as RNN, CNN, and LSTM are the most frequent methods used for text classification. This research aims to analyze the implementation of two deep learning methods combination, namely CNN and LSTM (C-LSTM), to classify Indonesian news texts. News texts used as data in this study were collected from Indonesian news portals. The obtained data were then divided into three categories based on their scope: "National," "International," and "Regional." Three research variables were tested in this study: the number of documents, the batch size value, and the learning rate value of the built C-LSTM. The experimental results showed that the F1-score obtained from the classification results using the C-LSTM method was $93.27 \%$. The F1-score value generated by the C-LSTM method was higher than that of CNN $(89.85 \%)$ and LSTM $(90.87 \%)$. In summary, the combination method of two deep learning methods, namely CNN and LSTM (C-LSTM), outperforms CNN and LSTM.
\end{abstract}

Intisari-Klasifikasi teks saat ini telah menjadi sebuah bidang yang banyak diteliti, khususnya terkait Natural Language Processing (NLP). Terdapat banyak metode yang dapat dimanfaatkan untuk melakukan klasifikasi teks, salah satunya adalah metode deep learning. RNN, CNN, dan LSTM merupakan beberapa metode deep learning yang umum digunakan untuk mengklasifikasikan teks. Makalah ini bertujuan menganalisis penerapan kombinasi dua buah metode deep learning, yaitu CNN dan LSTM (C-LSTM). Kombinasi kedua metode tersebut dimanfaatkan untuk melakukan klasifikasi teks berita bahasa Indonesia. Data yang digunakan adalah teks berita bahasa Indonesia yang dikumpulkan dari portal-portal berita berbahasa Indonesia. Data yang dikumpulkan dikelompokkan menjadi tiga kategori berita berdasarkan lingkupnya, yaitu "Nasional", "Internasional", dan "Regional". Dalam makalah ini dilakukan eksperimen pada tiga buah variabel penelitian, yaitu jumlah dokumen, ukuran batch, dan nilai learning rate dari C-LSTM yang dibangun. Hasil eksperimen menunjukkan bahwa nilai $F 1$ score yang diperoleh dari hasil klasifikasi menggunakan metode C-LSTM adalah sebesar 93,27\%. Nilai F1-score yang dihasilkan oleh metode C-LSTM lebih besar dibandingkan dengan CNN, dengan nilai $89,85 \%$, dan LSTM, dengan nilai 90,87\%. Dengan demikian, dapat disimpulkan bahwa kombinasi dua metode deep

1,2,3,4 Jurusan Teknik Komputer dan Informatika Politeknik Negeri Bandung, Jln. Gegerkalong Hilir, Ds. Ciwaruga, Kec. Parompong, Kab. Bandung Barat 40559 INDONESIA (tlp: 022-2015721; fax: 022-2013889; $\quad$ e-mail: $\quad{ }^{\text {goezthel@jtk.polban.ac.id; }}$ ${ }^{2}$ transmissia@jtk.polban.ac.id; ${ }^{3}$ ilham.gibran.tif417@polban.ac.id; ${ }^{4}$ muhammad.randi.tif417@polban.ac.id) learning, yaitu CNN dan LSTM (C-LSTM), memiliki kinerja yang lebih baik dibandingkan dengan CNN dan LSTM.

Kata Kunci-Deep Learning, CNN, LSTM, Klasifikasi Teks, Teks Berita.

\section{PENDAHULUAN}

Klasifikasi teks (text classification) telah menjadi bidang yang banyak diteliti di bidang Natural Language Processing (NLP) [1]. Penerapan klasifikasi teks telah banyak dilihat dalam kehidupan sehari-hari. Salah satu penerapan klasifikasi teks yang dapat ditemui adalah proses pengklasifikasian teks berita berdasarkan kategori tertentu. Saat ini, terdapat dua metode yang paling umum digunakan dalam melakukan klasifikasi teks, yaitu menggunakan metode tradisional (parametric algorithm) dan deep learning [2]. Dengan berkembangnya teknologi di bidang NLP, proses klasifikasi teks saat ini banyak dikembangkan dengan memanfaatkan teknologi neural network, salah satunya adalah deep learning. Deep learning terbukti dapat melakukan proses klasifikasi teks dengan sangat baik [3]-[5].

Berbagai algoritme deep learning telah dicoba untuk melakukan klasifikasi berita berdasarkan kategori tertentu. Metode Recurrent Neural Network (RNN) dan Long ShortTerm Memory (LSTM) adalah dua algoritme yang umum digunakan untuk mengenali data yang memiliki keterkaitan di dalamnya [6]. Kendati demikian, metode Convolutional Neural Network (CNN), yang umumnya digunakan untuk pemrosesan citra, juga memperlihatkan kinerja yang baik dalam mengklasifikasi teks [3].

Referensi [4], [7] mengombinasikan dua buah arsitektur deep learning, yaitu CNN dan LSTM untuk melakukan klasifikasi teks berita. Kombinasi dua arsitektur ini diberi nama Convolutional Long Short-Term Memory (C-LSTM). Referensi [4], [7] memperlihatkan akurasi C-LSTM yang lebih baik daripada CNN dan LSTM saat dibuat terpisah. Dataset yang digunakan adalah berita dengan bahasa Inggris dan bahasa Mandarin. Kedua penelitian ini memunculkan sebuah pertanyaan mengenai pemanfaatan C-LSTM untuk melakukan klasifikasi berita berupa teks dalam bahasa Indonesia. Oleh karena itu, dalam makalah ini dilakukan eksperimen terkait penerapan C-LSTM untuk melakukan klasifikasi berita teks berbahasa Indonesia.

\section{KLASIFIKASI TEKS}

Klasifikasi teks adalah proses pengelompokan teks atau dokumen ke dalam beberapa kategori atau kelas [1]. Secara 
umum, proses klasifikasi teks melibatkan beberapa tahapan, seperti ekstraksi fitur, dimension reduction, classifier selection, dan evaluation [1]. Telah banyak penelitian yang mencoba membahas proses klasifikasi teks dengan berbagai studi kasus yang berbeda. Studi kasus teks berita adalah salah satu studi kasus yang banyak diteliti saat ini. Metode deep learning adalah salah satu metode yang saat ini banyak digunakan untuk melakukan klasifikasi teks [2].

Terdapat sebuah penelitian yang fokus membahas berbagai metode yang dapat digunakan pada klasifikasi teks [1] Penelitian ini juga membahas secara sederhana tahapantahapan yang terdapat pada klasifikasi teks. Terdapat juga penelitian yang melakukan klasifikasi teks berita bahasa Indonesia dengan memanfaatkan metode $\mathrm{CNN}$ [3]. Penelitian tersebut menunjukkan bahwa $\mathrm{CNN}$, yang umumnya digunakan untuk menyelesaikan masalah terkait pengolahan citra, dapat juga diterapkan untuk menyelesaikan masalah terkait dengan NLP. CNN yang digunakan memanfaatkan convolution layer $1 D$ untuk mengekstrak fitur dari dalam berita [3]. CNN yang dibangun dapat melakukan klasifikasi dengan akurasi $\geq 90 \%$ pada test set yang digunakan.

Telah dilakukan juga penelitian yang sama-sama memanfaatkan CNN untuk melakukan klasifikasi berita bahasa Mandarin [8]. Namun, penelitian tersebut mencoba mengombinasikan CNN dengan Gated Recurrent Unit (GRU) dan Support Vector Machine (SVM) untuk membentuk sebuah voting system. Voting system yang dibangun mengklasifikasikan berita berdasarkan hasil voting dari ketiga metode yang digunakan. Metode yang dipilih dapat melakukan klasifikasi dengan akurasi sebesar $81 \%$ yang dihitung dengan memanfaatkan macro F1-score, yaitu nilai $F 1$-score yang dihitung dengan macro-average.

Referensi [2] mencoba memanfaatkan LSTM untuk mengklasifikasikan berita dengan bahasa Mandarin dan Inggris. LSTM dipilih karena kemampuannya dalam mengenali keterkaitan antar konteks di dalam dokumen teks [2], [4]. Metode yang dipilih mengombinasikan LSTM dengan hierarchical attentions untuk meningkatkan akurasi yang dihasilkan oleh LSTM. Penelitian ini juga menambahkan modul bidirectional pada LSTM untuk membuat LSTM mengenali keterkaitan konteks setelah dan sebelum kata yang sedang diolah. Metode yang dipilih menghasilkan akurasi $\geq$ $90 \%$ pada tiga dataset berita yang digunakan.

Penelitian lain mengombinasikan CNN dan LSTM untuk melakukan klasifikasi teks berita [4], [7]. CNN memiliki kelebihan dalam melakukan ekstraksi fitur karena didukung dengan convolution layer yang mampu melakukan ekstraksi fitur dengan lebih baik. Sementara itu, LSTM memiliki kelebihan dalam memperhatikan keterkaitan konteks di dalam dokumen berita.

Referensi [7] mencoba menyusun arsitektur CNN dan LSTM secara sequential. Data dimasukkan terlebih dahulu ke dalam LSTM, kemudian diproses lebih lanjut memanfaatkan CNN. Hal ini berbeda dengan penelitian yang mengombinasikan CNN dan LSTM secara paralel [4], sehingga kedua metode sama-sama dimanfaatkan untuk melakukan klasifikasi. Hasil yang diperoleh menunjukkan bahwa kombinasi $\mathrm{CNN}$ dan
LSTM menghasilkan akurasi klasifikasi yang lebih baik daripada CNN maupun LSTM yang tidak dikombinasikan [4], [7].

\section{PENGEMBANGAN C-LSTM}

Bagian ini secara khusus menjelaskan proses pengembangan metode C-LSTM yang digunakan untuk melakukan pengklasifikasian teks. Metode C-LSTM sebenarnya telah diajukan pada penelitian sebelumnya [4]. Namun, makalah ini mengimplementasikan metode C-LSTM untuk teks berita yang berbeda dengan penelitian pada [4]. Pengembangan metode dilakukan dengan arsitektur yang terdapat pada [4], tetapi dengan pengaturan hyperparameter yang berbeda.

\section{A. Dataset}

Dataset yang digunakan dalam makalah ini adalah berita dalam bentuk teks. Teks berita dikumpulkan dari portal berita Detik, Suara, CNN Indonesia, Tribun, Tempo, dan Kompas. Terdapat 5.000 dokumen berita yang berhasil dikumpulkan. Teks berita yang dikumpulkan kemudian disimpan sebagai plain text di dalam file dengan format comma separated value (CSV). Penyimpanan di dalam file CSV dilakukan untuk mempermudah proses pembacaan dokumen berita pada tahap data labeling dan text pre-processing. Pada tahap data labeling, teks berita dikelompokkan ke dalam tiga buah kategori, yaitu "Internasional", "Nasional", dan "Regional".

\section{B. Pre-processing Dokumen Berita}

Dokumen berita yang telah dikumpulkan tidak dapat langsung digunakan untuk proses pelatihan machine learning yang dibangun. Dokumen berita perlu melalui tahapan text preprocessing untuk mempersiapkan dokumen berita sehingga dapat digunakan untuk pelatihan machine learning. Tahapan text pre-processing bertujuan untuk membersihkan teks berita yang diperoleh.

Pembersihan teks disini memiliki arti menyelaraskan format penulisan dokumen berita, sehingga lebih mudah diakses pada saat pelatihan berlangsung. Tahap text pre-processing juga dilakukan sebagai usaha meningkatkan kinerja pengklasifikasian C-LSTM, yaitu dengan menyesuaikan dokumen berita yang diperoleh agar mudah dipahami oleh CLSTM yang dibangun.

Terdapat beberapa tahapan text processing yang dilaksanakan, seperti ditunjukkan pada Gbr. 1. Tahapan tersebut yaitu stopword removal, special character removal, case folding, stemming, dan data splitting. Seluruh tahapan preprocessing ini dilakukan setelah dokumen berita diberi label untuk mengidentifikasi masing-masing kategori pada berita.

Stopword removal adalah sebuah tahapan pada text preprocessing yang berfungsi menghilangkan kata-kata yang tidak memiliki makna khusus, misalnya kata hubung, seperti 'dan', 'karena', dan 'tetapi'. Kata hubung perlu dihilangkan karena sering muncul dan berpotensi memengaruhi kinerja pengklasifikasikan C-LSTM.

Special character removal adalah tahapan untuk menghilangkan tanda baca dan karakter-karakter lainnya yang tidak memiliki makna khusus. Sama halnya dengan stopword yang sering muncul, karakter-karakter seperti tanda baca juga 

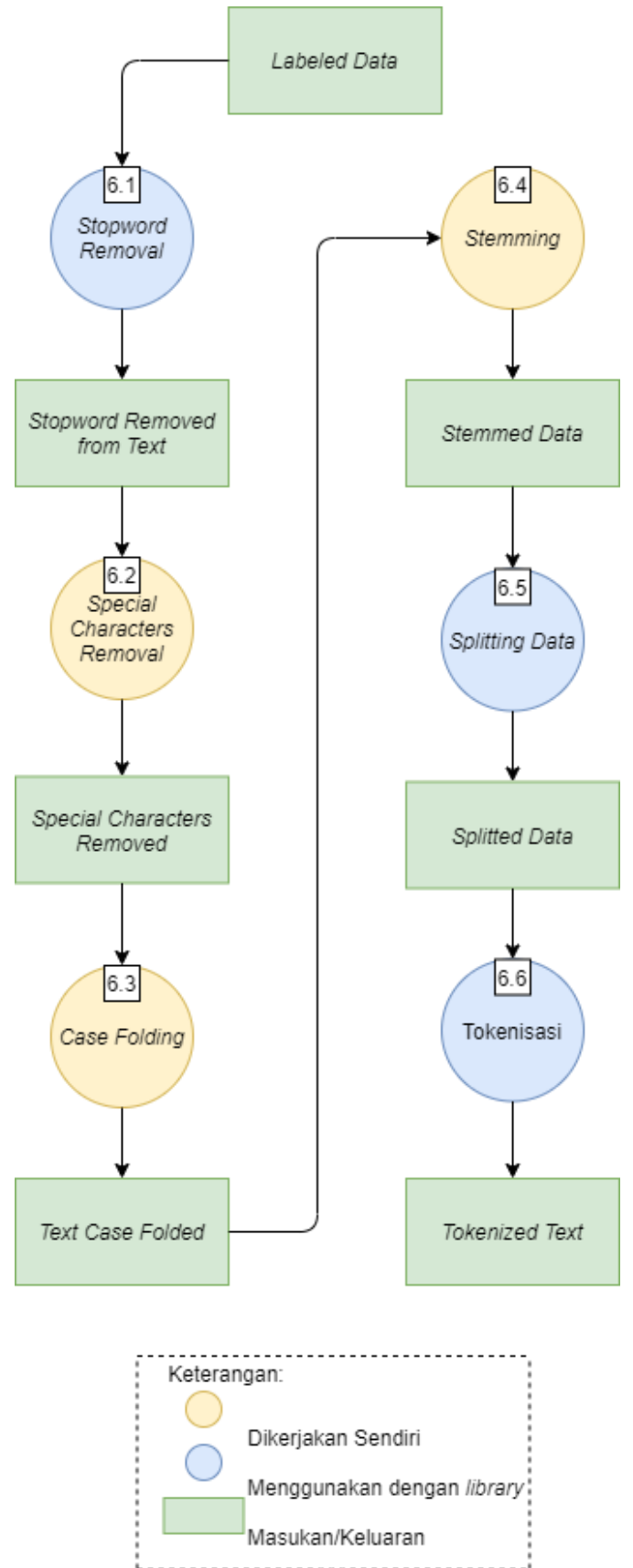

Gbr. 1 Tahapan pre-processing yang dilakukan.

dapat memengaruhi kinerja pengklasifikasian oleh machine learning.

Tahapan data pre-processing selanjutnya adalah case folding, yang bertujuan untuk menyamaratakan bentuk hurufhuruf pada data teks. Pada makalah ini, karakter yang terdapat di dalam dokumen berita dikonversi ke dalam bentuk lowercase.

Stemming adalah proses transformasi setiap kata pada teks berita menjadi bentuk kata dasarnya. Konversi ke dalam bentuk kata dasar bertujuan untuk menyelaraskan pemaknaan dari suatu kata. Selain itu, stemming juga dapat mempermudah machine learning dalam mengolah dan mengenali kata yang terdapat pada dokumen berita.
Proses terakhir adalah proses data splitting, yang berfungsi membagi dataset menjadi data latih dan data uji. Pembagian dataset ini bertujuan untuk memastikan bahwa berita yang digunakan untuk menguji C-LSTM yang telah dilatih berbeda dengan dokumen yang dimanfaatkan untuk pelatihan. Dengan demikian, perhitungan terhadap kinerja pengklasifikasian dapat dinilai dengan lebih baik. Melalui pemisahan jenis dataset ini, dapat juga diperoleh pengetahuan tentang C-LSTM yang dibangun, yaitu mengalami overfitting atau tidak. Overfitting adalah kondisi saat machine learning memiliki kinerja klasifikasi yang baik hanya saat pelatihan dilakukan, tetapi kurang baik saat pengujian dilakukan.

\section{Convolutional Neural Network (CNN)}

CNN merupakan jenis deep learning yang memanfaatkan convolutional layer sebagai penyusun neural network yang dibangun. Banyak penelitian yang membuktikan bahwa CNN lebih baik daripada metode lain dalam melakukan pengolahan teks. Telah dinyatakan bahwa convolutional layer pada CNN dapat mengurangi beban komputasi dari neural network [9]. Hal ini terjadi karena convolutional layer pada dasarnya adalah sebuah sparse matrix yang dimensinya lebih kecil dari dimensi data yang diolah.

Teknik konvolusi adalah teknik untuk mengalikan matriks masukan dengan matriks bernama kernel untuk menghasilkan keluaran. Teknik konvolusi melakukan perkalian matriks dengan cara yang berbeda dengan perkalian matriks pada umumnya. Pada formula matematis, operasi konvolusi umumnya disimbolkan dengan tanda asterik (*) [9]. Persamaan (1) menunjukkan formula dasar proses konvolusi.

$$
s(x)=(I * K)(x)=\sum_{n} I(n-x) K(n) .
$$

Pada (1), I adalah masukan dari proses konvolusi. Pada text processing, I merupakan matriks yang merepresentasikan teks yang diolah. Kemudian, $K$ adalah kernel dari proses konvolusi yang ukurannya ditentukan sendiri dan $s$ adalah nilai keluaran dari proses konvolusi. Pada bidang machine learning, keluaran proses konvolusi biasanya disebut dengan feature map [9].

Metode CNN umumnya dimanfaatkan untuk mengolah citra karena convolution layer dapat dengan mudah mengekstrak fitur-fitur kecil dari suatu citra. Namun, beberapa penelitian telah menerapkan CNN untuk melakukan pengolahan teks berita [3], [8]. Hasil akurasi yang ditunjukkan oleh kedua penelitian tersebut juga dapat dikatakan cukup baik karena memiliki akurasi $\geq 80 \%$.

\section{Long Short-Term Memory (LSTM)}

LSTM merupakan pengembangan dari metode RNN melalui penambahan sel (cell) LSTM di dalam arsitektur RNN. LSTM telah sukses menyelesaikan berbagai permasalahan, seperti handwriting recognition, speech recognition, handwriting generation, dan image captioning [9]. LSTM memungkinkan arsitektur machine learning menyimpan bobot (weight) dari suatu perhitungan lebih lama dari RNN. Hal ini disebabkan LSTM memiliki sel-sel LSTM, yaitu sebuah node yang memiliki self-recurrent. Hal ini menyebabkan LSTM dapat bekerja lebih baik daripada RNN pada data dengan sekuens yang lebih panjang [9]. 
Pada LSTM, proses recurrent atau perulangan dilakukan pada level node dan layer. Sel-sel LSTM dikendalikan oleh input gate untuk mengingat atau melupakan informasi yang dimiliki berdasarkan keluaran dari LSTM. Referensi [2] mengimplementasikan LSTM untuk melakukan klasifikasi teks. Hasil yang diperoleh juga dapat dikatakan cukup baik dengan nilai akurasi $\geq 90 \%$.

\section{E. Convolutional Long Short-Term Memory (C-LSTM)}

CNN dan LSTM adalah dua buah metode yang paling umum digunakan untuk menyelesaikan masalah terkait klasifikasi teks [6]. Akan tetapi, CNN yang dimanfaatkan untuk melakukan pengolahan teks sering kali mengabaikan keterkaitan antar konteks di dalam dokumen teks [2], [4]. Hal ini menyebabkan banyak peneliti mengganti metode CNN dengan LSTM. Walaupun LSTM memiliki kelebihan untuk memproses keterkaitan antar konteks di dalam teks, CNN masih lebih unggul daripada LSTM dalam proses ekstraksi fitur atau mengambil fitur di dalam dokumen teks. Oleh karena itu, dikombinasikan CNN dan LSTM untuk memperoleh kelebihan masing-masing metode [4], [7].

Referensi [4] menggabungkan CNN dan LSTM secara paralel, sehingga dokumen berita yang dimasukkan ke dalam arsitektur machine learning diproses secara bersamaan oleh CNN dan LSTM. Hasil dari kedua metode ini kemudian digabungkan untuk memperoleh hasil pengklasifikasian yang dilakukan. Hasil penggabungan kedua metode ini memperlihatkan akurasi yang lebih baik daripada saat kedua metode tersebut dibuat terpisah [4].

Arsitektur C-LSTM yang digunakan pada makalah ini ditunjukkan pada Gbr. 2. Arsitektur yang dibangun adalah hasil konstruksi ulang rancangan yang terdapat pada [4]. Namun, pada makalah ini dilakukan modifikasi untuk mengatasi overfitting yang terjadi pada arsitektur C-LSTM.

\section{F. Pengaturan Hyperparameter C-LSTM}

Referensi [4] memperlihatkan kerangka arsitektur C-LSTM yang digunakan untuk melakukan klasifikasi teks. Namun, tidak disampaikan nilai hyperparameter yang digunakan untuk membangun C-LSTM yang diajukan [4]. Oleh karena itu, dilakukan proses pengaturan hyperparameter pada makalah ini. Pengaturan hyperparameter dilakukan melalui proses studi pada penelitian sejenis terkait klasifikasi teks, khususnya klasifikasi teks berita.

Hyperparameter juga dapat diperoleh dengan metode grid search, yaitu metode untuk mencobakan kombinasi beberapa hyperparameter, kemudian membandingkan setiap kombinasi dengan metrik perhitungan yang sama. Akan tetapi, pemilihan nilai kombinasi dari hyperparameter yang digunakan pada grid search tetap merujuk dari beberapa sumber, seperti penelitian terkait klasifikasi teks dan artikel terkait pengimplementasian deep learning. Grid search dipilih karena mudah untuk diimplementasikan. Grid search juga cukup efektif untuk melakukan tuning pada variasi jumlah hyperparameter yang tidak terlalu besar [10]. Tabel I memperlihatkan pengaturan hyperparameter yang digunakan untuk membangun C-LSTM pada makalah ini.

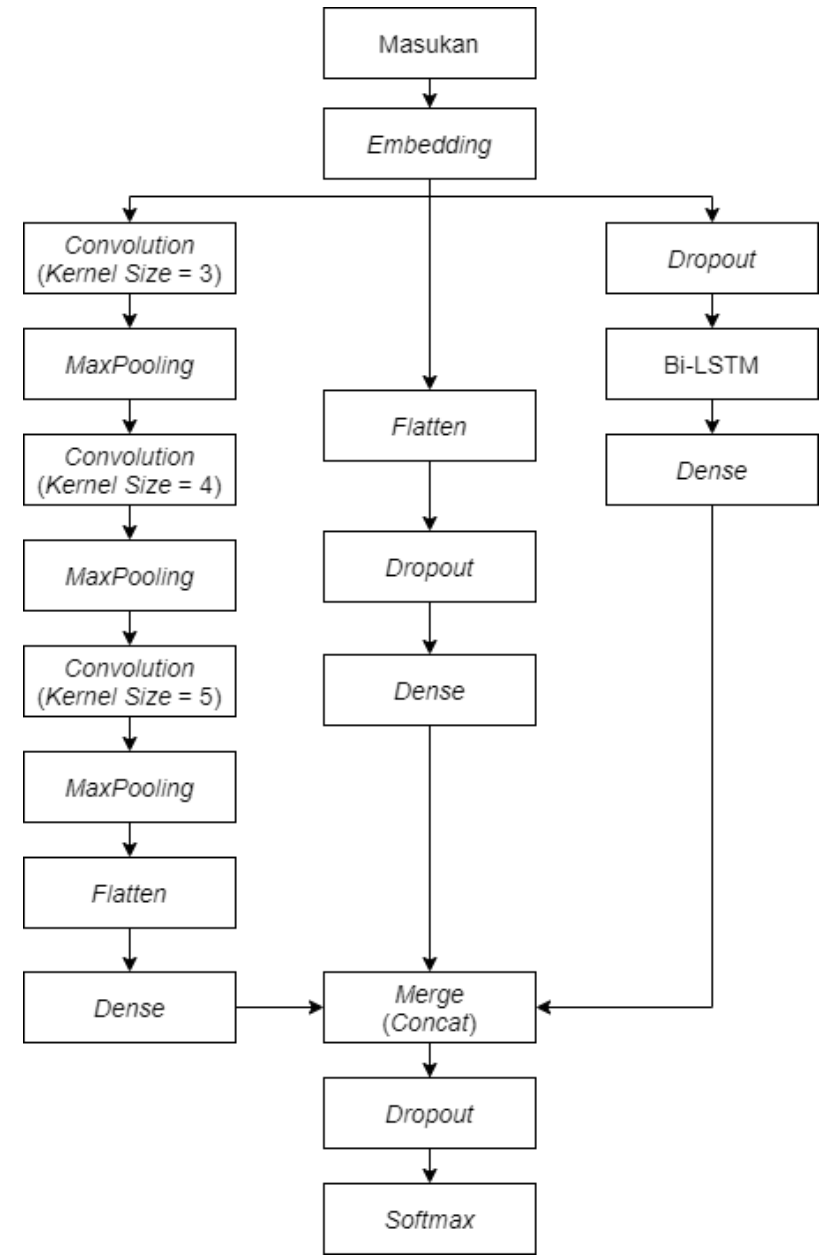

Gbr. 2 Arsitektur C-LSTM.

\section{HASIL DAN PEMBAHASAN}

Setelah membangun metode C-LSTM dan mengatur hyperparameter pada metode tersebut, dilakukan sebuah eksperimen untuk mengamati kinerja metode C-LSTM dalam mengklasifikasi berita berbahasa Indonesia. Eksperimen dilakukan pada tiga buah nilai, yaitu jumlah dokumen untuk latihan, nilai learning rate, dan ukuran batch. Gbr. 3 memperlihatkan variasi masing-masing nilai dan cara nilai tersebut dikombinasikan. Terlihat pada Gbr. 3 bahwa variasi nilai yang telah disebutkan sebelumnya dikombinasikan satu sama lain secara cross-product. Hal ini dilakukan untuk memperkaya skenario eksperimen yang dilakukan.

Dokumen yang digunakan untuk melakukan pelatihan dibentuk dari dataset yang dimiliki. Pemilihan subset dokumen yang digunakan dilakukan secara acak (random sampling). Akan tetapi, jumlah dokumen untuk masing-masing kategori tetap diatur dengan komposisi yang sama.

\section{A. Metrik Perhitungan Kinerja C-LSTM}

Untuk mempermudah perhitungan kinerja metode C-LSTM, digunakan sebuah metrik perhitungan $F 1$-score untuk menilai kemampuan metode C-LSTM melakukan klasifikasi teks bahasa Indonesia. Nilai F1-score dihitung dengan memanfaatkan dua buah metrik perhitungan lainnya, yaitu 
TABEL I

PENGATURAN HYPERPARAMETER YANG DIGUNAKAN

\begin{tabular}{|c|c|c|}
\hline Hyperparameter & $\begin{array}{c}\text { Nilai } \\
\text { yang } \\
\text { Dipilih } \\
\end{array}$ & Sumber \\
\hline $\begin{array}{l}\text { Jumlah node pada } \\
\text { convolutional layer }\end{array}$ & 300 & $\begin{array}{lr}\text { Penelitian yang membahas } \\
\text { pemanfaatan CNN } \\
\text { klasifikasi teks [3] }\end{array}$ \\
\hline $\begin{array}{l}\text { Jumlah node pada } \\
\text { LSTM dan dense } \\
\text { layer }\end{array}$ & 128 & $\begin{array}{l}\text { Grid search terhadap lima nilai, } \\
\text { yaitu } 32,64,128,256 \text {, dan } 512 \text {. }\end{array}$ \\
\hline $\begin{array}{l}\text { Dropout rate pada } \\
\text { dropout layer }\end{array}$ & 0,6 & $\begin{array}{l}\text { Grid search terhadap sembilan } \\
\text { nilai yaitu } 0,1-0,9 \text {. Nilai ini } \\
\text { dipilih untuk memeriksa seluruh } \\
\text { kemungkinan nilai dropout. }\end{array}$ \\
\hline $\begin{array}{l}\text { Dropout rate pada } \\
\text { LSTM layer }\end{array}$ & 0,9 & $\begin{array}{l}\text { Grid search terhadap sembilan } \\
\text { nilai, yaitu } 0,1-0,9 \text {. Nilai ini } \\
\text { dipilih untuk memeriksa seluruh } \\
\text { kemungkinan nilai dropout. }\end{array}$ \\
\hline Weight norm & 1 & $\begin{array}{l}\text { Grid search terhadap lima nilai, } \\
\text { yaitu } 1-5 \text {. Nilai ini diperoleh dari } \\
\text { hasil membaca artikel mengenai } \\
\text { proses mengatasi overfitting pada } \\
\text { deep learning. }\end{array}$ \\
\hline Regularizer & 0,001 & $\begin{array}{l}\text { Grid search pada empat nilai, } \\
\text { yaitu } 0,1 ; 0,01 ; 0,001 ; \text { dan } \\
0,0001 \text {. Nilai ini diperoleh dari } \\
\text { hasil membaca artikel mengenai } \\
\text { proses mengatasi overfitting pada } \\
\text { deep learning. }\end{array}$ \\
\hline Optimizer & Adam & $\begin{array}{l}\text { Grid search terhadap beberapa } \\
\text { variasi } \text { optimizer yang tersedia di } \\
\text { library Keras (RMSprop, Adam, } \\
\text { SGD, dan Adamax). Namun, } \\
\text { rancangan asli dari C-LSTM } \\
\text { memanfaatkan Adam sebagai } \\
\text { optimizer. }\end{array}$ \\
\hline $\begin{array}{l}\text { Activation function } \\
\text { (hidden layer) }\end{array}$ & ReLu & $\begin{array}{l}\text { Grid search pada variasi } \\
\text { activation function yang tersedia } \\
\text { di library Keras (ReLu, Softplus, } \\
\text { Softsign, TanH, dan Sigmoid). } \\
\text { Akan tetapi, beberapa penelitian } \\
\text { memanfaatkan ReLu sebagai } \\
\text { activation function dari hidden } \\
\text { layer pada arsitektur deep } \\
\text { learning yang dibangun untuk } \\
\text { melakukan text classification [2]- } \\
{[4],[6] .}\end{array}$ \\
\hline
\end{tabular}

precision dan recall. Persamaan (2) dan (3) memperlihatkan rumus untuk menghitung nilai precision dan recall.

$$
\begin{gathered}
\text { precision }=\frac{T P}{T P+F P} \\
\text { recall }=\frac{T P}{T P+F N}
\end{gathered}
$$

dengan TP adalah true positive, yang menunjukkan jumlah dokumen berita pada suatu kategori yang berhasil diklasifikasi dengan benar oleh C-LSTM; FP adalah false positive, menunjukkan jumlah berita dengan kategori tertentu yang dikategorikan dengan kurang tepat; sedangkan $F N$ adalah false negative, yang menunjukkan jumlah berita yang diklasifikasikan sebagai suatu kategori tertentu, tetapi

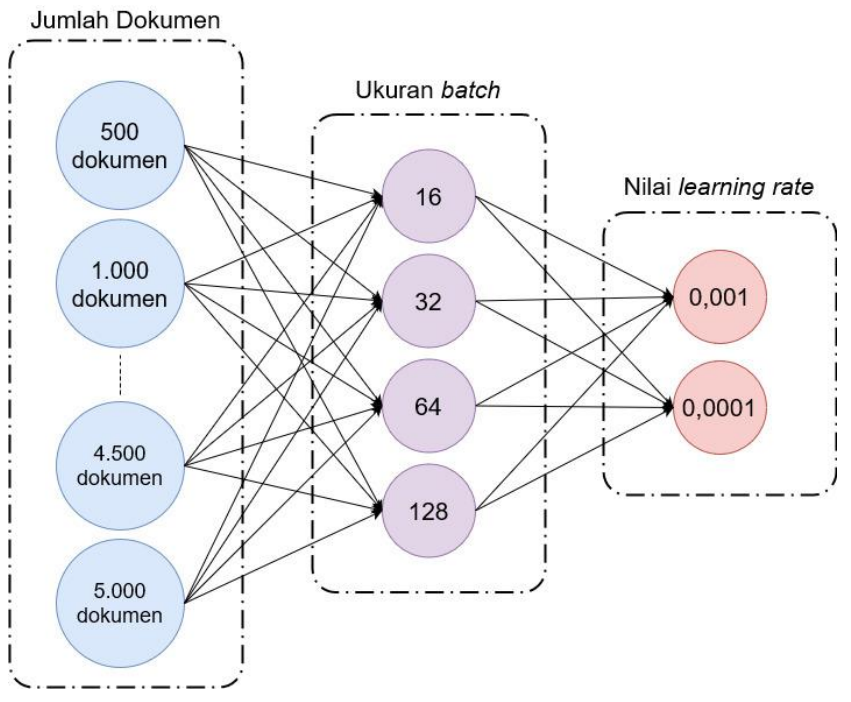

Gbr. 3 Kombinasi variabel eksperimen.

TABEL II

PENGARUH JUMLAH DOKUMEN LATIH PADA F1-SCORE

\begin{tabular}{|r|r|}
\hline Jumlah Dokumen & Nilai F1-Score \\
\hline 500 & 0,2789 \\
\hline 1.000 & 0,6312 \\
\hline 1.500 & 0,6917 \\
\hline 2.000 & 0,7537 \\
\hline 2.500 & 0,7896 \\
\hline $\mathbf{3 . 0 0 0}$ & $\mathbf{0 , 8 6 6 3}$ \\
\hline 3.500 & 0,8396 \\
\hline 4.000 & 0,8413 \\
\hline 4.500 & 0,8802 \\
\hline $\mathbf{5 . 0 0 0}$ & $\mathbf{0 , 8 9 3 4}$ \\
\hline &
\end{tabular}

sebenarnya bukan merupakan kategori tersebut. Nilai precision dan recall dihitung untuk masing-masing kategori, sehingga meski $F P$ dan $F N$ sama-sama menunjukkan klasifikasi yang salah, tetapi perhitungan untuk kedua nilai tersebut bisa jadi berbeda. Persamaan (4) menunjukkan rumus untuk menghitung F1-score yang dijadikan metrik perbandingan pada makalah ini.

$$
F 1-\text { score }=\frac{2 \times(\text { recall } \times \text { precision })}{(\text { recall }+ \text { precision })}
$$

Nilai F1-score yang dihitung menggunakan (4) dijadikan metrik perhitungan kinerja C-LSTM dalam mengklasifikasikan berita bahasa Indonesia dengan tiga buah kategori ("Internasional", "Nasional", dan "Regional"). Nilai ini dipilih karena mampu memperlihatkan perhitungan yang sensitif terhadap dataset yang memiliki minor class di dalamnya [11].

\section{B. Pengaruh Jumlah Dokumen Latih pada F1-Score}

Jumlah dokumen latih adalah salah satu faktor yang berpengaruh terhadap kinerja suatu machine learning. Tabel II memperlihatkan pengaruh jumlah dokumen latih terhadap nilai F1-score pada masing-masing variasi yang telah ditentukan. Nilai F1-score yang terdapat pada Tabel II merupakan nilai rerata F1-score untuk seluruh skenario eksperimen yang dilakukan. Seperti yang telah disampaikan sebelumnya, proses eksperimen dilakukan dengan mengombinasikan seluruh 
variasi nilai yang terdapat pada Gbr. 2. Oleh karena itu, nilai 0,8934 pada jumlah dokumen 5.000 diperoleh dengan meratarata hasil F1-score untuk jumlah dokumen 5.000 dengan berbagai variasi learning rate dan ukuran batch.

Terlihat pada Tabel II bahwa nilai F1-score mengalami peningkatan seiring dengan bertambahnya jumlah dokumen yang digunakan untuk pelatihan metode C-LSTM. Pada Tabel II juga terlihat sebuah titik jenuh pada jumlah dokumen 3.000. Titik jenuh merupakan titik ketika nilai $F 1$-score sudah berhenti mengalami peningkatan yang signifikan. Kendati nilai F1-score bisa mencapai 0,8934 atau $89,34 \%$ pada jumlah dokumen 5.000, peningkatan yang diperoleh dari jumlah dokumen 3.000 ke 5.000 hanya sebesar 0,0271 (2,71\%). Nilai ini tentunya tidak terlalu signifikan jika dibandingkan dengan peningkatan dari jumlah dokumen sebanyak 2.500 ke 3.000 .

\section{Pengaruh Ukuran Batch pada F1-Score}

Ukuran batch adalah salah satu hyperparameter yang memengaruhi kinerja suatu neural network. Hal ini terjadi karena ukuran batch secara tidak langsung dapat memengaruhi besarnya bobot yang terdapat dalam arsitektur neural network [12], [13]. Pada penelitian yang dilakukan, ukuran batch menjadi salah satu nilai yang diamati pengaruhnya terhadap F1-score C-LSTM.

Gbr. 4 memperlihatkan grafik pengaruh ukuran batch terhadap nilai $F 1$-score. Nilai $F 1$-score yang terdapat pada Gbr. 4 diperoleh dengan merata-rata nilai $F 1$-score dengan ukuran batch yang sama. Hal ini dilakukan untuk melihat secara umum pengaruh ukuran batch terhadap F1-score. Terlihat dari Gbr. 4, ukuran batch 16 menunjukkan rata-rata $F 1$-score yang lebih baik daripada ukuran batch lainnya, yaitu mendekati 0,8 (80\%).

Terlihat adanya keterkaitan secara negatif antara ukuran batch dengan F1-score. Hal ini dilihat dari menurunnya nilai F1-score seiring bertambahnya ukuran batch. Hal ini bisa jadi dipengaruhi oleh jumlah batch yang terbentuk saat pelatihan dilakukan. Ukuran batch yang lebih kecil pasti akan menghasilkan jumlah batch yang lebih banyak daripada ukuran batch yang besar pada jumlah dokumen latih yang sama. Hal ini juga tentunya berpengaruh pada waktu pelatihan yang dibutuhkan. Jumlah batch yang lebih banyak tentunya akan membutuhkan waktu yang lebih lama dalam proses pelatihan C-LSTM.

Dengan demikian, pemilihan ukuran batch yang lebih kecil seperti 16 atau 32 sangat disarankan untuk meningkatkan nilai F1-score dari proses klasifikasi teks berita bahasa Indonesia memanfaatkan C-LSTM. Ukuran batch 32 masih dapat dipilih karena dapat menghasilkan F1-score yang masih cukup tinggi, tetapi dengan waktu pelatihan yang lebih cepat daripada ukuran batch 16.

\section{Pengaruh Nilai Learning Rate pada F1-Score}

Sama halnya dengan ukuran batch, learning rate adalah salah satu hyperparameter yang dapat memengaruhi bobot yang terdapat dalam arsitektur neural network. Pada makalah ini, dipilih dua buah learning rate, yaitu 0,001 dan 0,0001. Kedua learning rate ini diamati pengaruhnya terhadap nilai $F 1$ score. Gbr. 5 memperlihatkan grafik perbandingan nilai learning rate terhadap F1-score C-LSTM. Seperti yang dapat

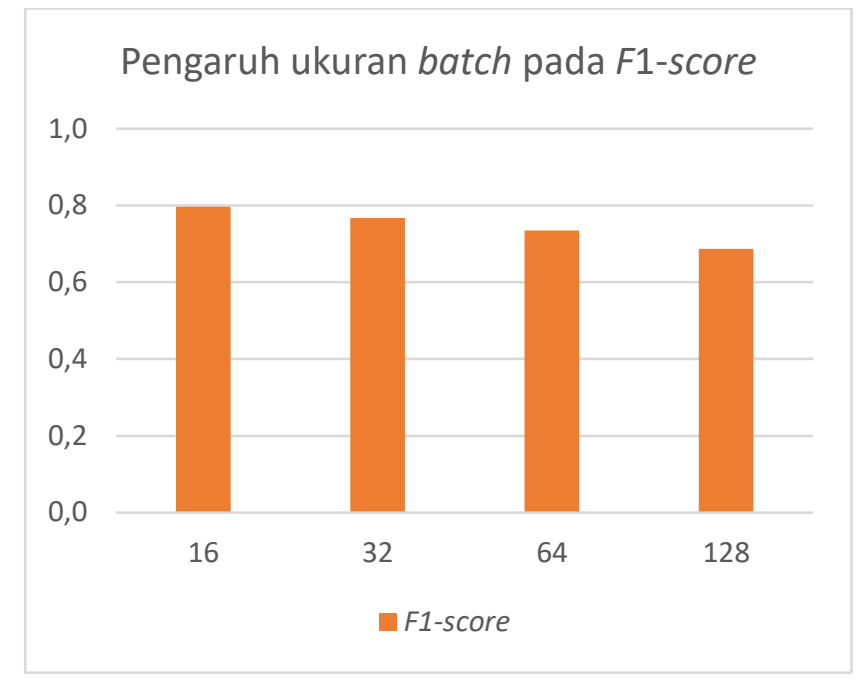

Gbr. 4 Grafik pengaruh ukuran batch pada F1-score.

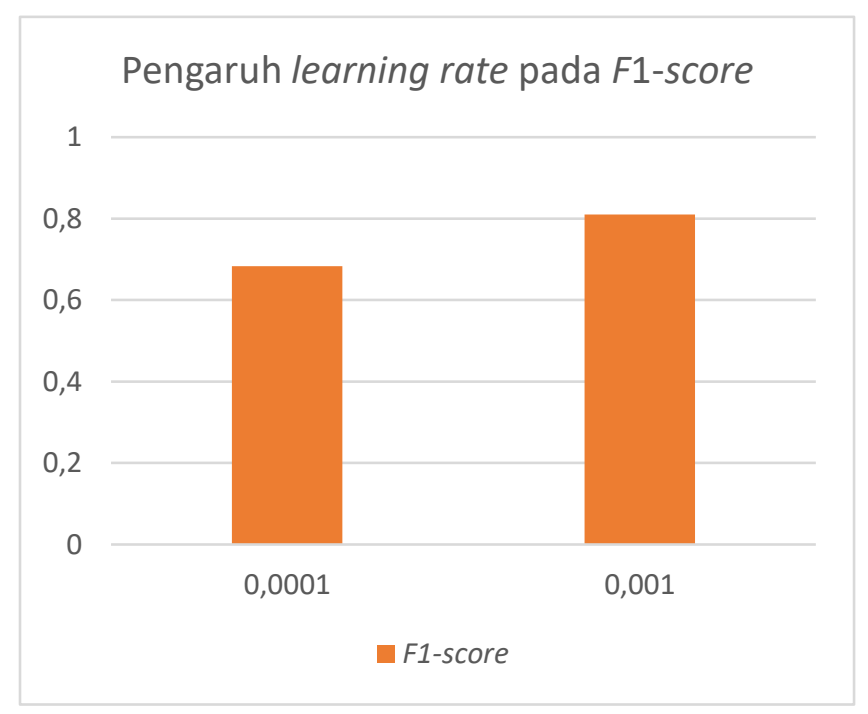

Gbr. 5 Pengaruh learning rate pada F1-score.

dilihat, nilai learning rate 0,001 memperlihatkan F1-score yang lebih tinggi, yaitu $0,8098(80,98 \%)$. Nilai ini lebih baik $0,1264(12,64 \%)$ dari learning rate sebesar 0,0001 .

Meskipun learning rate 0,001 lebih baik daripada 0,0001, learning rate tidak boleh diatur terlalu besar ataupun terlalu kecil. Hal ini perlu dilakukan untuk memastikan machine learning mempelajari data dengan baik. Besarnya learning rate dapat memengaruhi kecepatan machine learning dalam melakukan pembelajaran, sehingga nilai learning rate 0,001 adalah besaran yang disarankan pada penggunaan C-LSTM dalam makalah ini.

\section{E. Kinerja C-LSTM pada Hyperparameter Pilihan}

Berdasarkan eksperimen terhadap berbagai hyperparameter, ukuran batch 16 menghasilkan nilai $F 1$-score yang paling baik di antara ukuran batch lainnya, sehingga dalam membangun CLSTM, ukuran batch 16 adalah yang disarankan untuk digunakan. Begitu pula dengan nilai learning rate sebesar 0,001, yang merupakan nilai default dari optimizer Adam yang digunakan saat membangun C-LSTM. Oleh karena itu, pada 
TABEL III

FI-SCORE C-LSTM DENGAN HYPERPARAMETER TERPILIH

\begin{tabular}{|r|r|}
\hline Jumlah Dokumen & \multicolumn{1}{|c|}{ F1-Score } \\
\hline 500 & 0,5748 \\
\hline 1.000 & 0,7302 \\
\hline 1.500 & 0,8077 \\
\hline $\mathbf{2 . 0 0 0}$ & $\mathbf{0 , 8 7 2 5}$ \\
\hline 2.500 & 0,8920 \\
\hline 3.000 & 0,9187 \\
\hline 3.500 & 0,9153 \\
\hline 4.000 & 0,9202 \\
\hline 4.500 & 0,9203 \\
\hline $\mathbf{5 . 0 0 0}$ & $\mathbf{0 , 9 3 2 7}$ \\
\hline
\end{tabular}

makalah ini, C-LSTM diatur menggunakan ukuran batch sebesar 16 dan learning rate 0,001 , sebelum dibandingkan nilai F1-score-nya dengan metode lain, seperti LSTM dan CNN. Tabel III memperlihatkan nilai F1-score untuk C-LSTM yang telah diatur ukuran batch dan learning rate-nya pada variasi jumlah dokumen berita yang terdapat pada Gbr. 3 .

Terlihat pada Tabel III bahwa C-LSTM dengan ukuran batch dan learning rate terpilih menghasilkan nilai F1-score yang lebih baik, dengan F1-score mencapai 0,9327 (93,27\%). Terlihat juga bahwa titik jenuh pada C-LSTM dengan hyperparameter terpilih terdapat pada jumlah dokumen berita sebanyak 2.000 berita. Jumlah dokumen 2.000 dianggap sebagai titik jenuh karena peningkatan yang terjadi setelah titik tersebut tidak lagi signifikan seperti sebelum titik tersebut.

Berdasarkan Tabel III, dapat diambil kesimpulan bahwa jumlah dokumen memang benar berpengaruh terhadap nilai F1-score. Namun, jika dibandingkan dengan Tabel II, terlihat bahwa terdapat pergeseran titik jenuh saat hyperparameter diatur dengan spesifik. Penggunaan ukuran batch 16 dan learning rate 0,001 terlihat memberikan dampak positif bagi $\mathrm{C}$ LSTM, karena dengan jumlah dokumen yang sama, nilai $F 1$ score yang diperoleh berada di atas rata-rata F1-score seperti yang terlihat pada Tabel II.

\section{F. Perbandingan C-LSTM dengan LSTM dan CNN}

Subbagian ini secara khusus membahas perbandingan nilai F1-score dari C-LSTM, CNN, dan LSTM. Perbandingan dilakukan untuk melihat nilai F1-score C-LSTM, lebih baik daripada CNN dan LSTM atau tidak, pada studi kasus berita berbahasa Indonesia. Gbr. 6 memperlihatkan perbandingan CNN, LSTM, dan C-LSTM untuk klasifikasi teks berita bahasa Indonesia. Dataset yang digunakan untuk membandingkan CLSTM, CNN, dan LSTM adalah dataset dokumen berita dengan jumlah 5.000 dokumen berita.

Dapat dilihat pada Gbr. 6 bahwa C-LSTM memiliki nilai $F 1$ score yang lebih baik daripada CNN maupun LSTM. C-LSTM memiliki nilai $F 1$-score 2,4\% lebih baik dari LSTM dan 3,42\% lebih baik dari CNN. Dari sini dapat dilihat bahwa C-LSTM memiliki kinerja (nilai $F 1$-score) yang lebih baik daripada CNN maupun LSTM saat tidak digabungkan.

Tabel IV juga memperlihatkan bahwa C-LSTM cukup sensitif pada kategori "Regional", yang memiliki jumlah dokumen berita lebih sedikit daripada "Nasional" dan

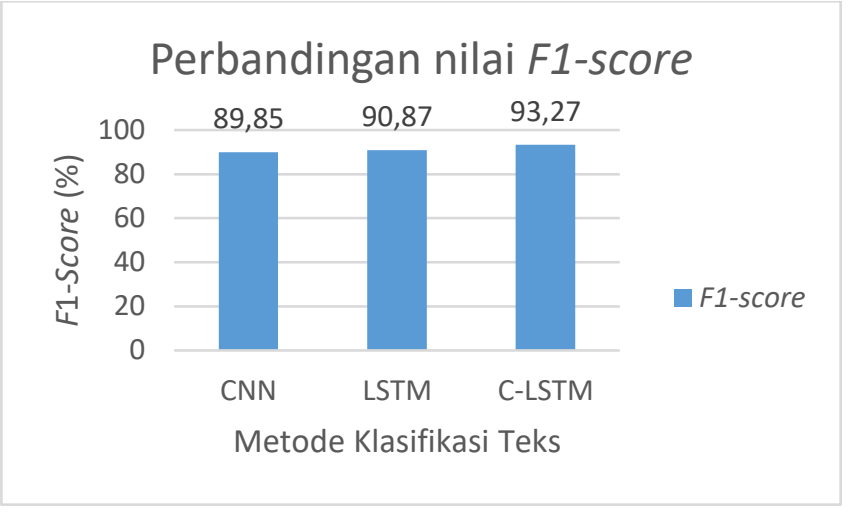

Gbr. 6 Perbandingan F1-score CNN, LSTM, dan C-LSTM.

TABEL IV

NILAI F1-SCORE PER KATEGORI UNTUK C-LSTM

\begin{tabular}{|l|c|c|c|r|}
\hline \multicolumn{1}{|c|}{ Kategori } & Precision & Recall & F1-Score & $\begin{array}{c}\text { Jumlah } \\
\text { Dokumen }\end{array}$ \\
\hline Internasional & 0,9437 & 0,9153 & 0,9293 & 366 \\
\hline Nasional & 0,9398 & 0,9690 & 0,9542 & 548 \\
\hline Regional & 0,8889 & 0,7442 & 0,8101 & 86 \\
\hline Rata-rata & 0,9368 & 0,9300 & 0,9327 & \\
\hline
\end{tabular}

"Internasional". Hal ini dapat dilihat dari nilai precision, recall, dan F1-score untuk kategori "Regional" yang cukup baik. Dari sini dapat dilihat bahwa C-LSTM yang dibangun mampu mengklasifikasikan dokumen berita bahasa Indonesia dengan baik.

\section{KESIMPULAN}

Dari penelitian yang telah dilakukan, dapat ditarik kesimpulan bahwa dalam mengklasifikasikan berita berbahasa Indonesia terdapat dua buah metode yang umum digunakan, yaitu CNN dan LSTM. Kedua metode ini dapat dikombinasikan untuk membentuk sebuah metode baru dengan nama C-LSTM. Metode C-LSTM terlihat memiliki kinerja yang lebih baik daripada kedua metode pendahulunya (CNN dan LSTM). Hal ini dapat dilihat dari nilai F1-score yang melebihi kedua metode lainnya. C-LSTM dapat memperoleh nilai $F 1$-score sebesar $0,9327(93,27 \%)$ pada dataset berita yang dipilih, lebih baik 2,4\% dari LSTM dan lebih baik 3,42\% dari CNN.

Pada penelitian ini juga terlihat bahwa C-LSTM yang dibangun cukup sensitif untuk mengklasifikasikan dokumen berita. Hal ini terlihat dari nilai precision, recall, dan F1-score yang cukup tinggi untuk kategori "Regional" yang lebih sedikit daripada kategori "Nasional" dan "Internasional".

Eksperimen untuk melihat hyperparameter terbaik juga telah dilakukan. Ukuran batch dan learning rate terlihat memengaruhi nilai F1-score dari pengklasifikasian berita. Ukuran batch yang lebih kecil terlihat menghasilkan nilai $F 1$ score yang lebih tinggi daripada ukuran batch yang besar. Oleh karena itu, pada makalah ini, ukuran batch 16 dipilih sebagai hyperparameter. Sementara itu, learning rate yang dipilih adalah learning rate dengan nilai 0,001, yang merupakan nilai default dari optimizer Adam yang digunakan.

Dari pengujian yang dilakukan, diketahui juga bahwa terdapat titik jenuh pada jumlah dokumen 2.000 untuk C- 
LSTM yang dipilih. Maka, dapat ditarik kesimpulan bahwa dengan dokumen berita sebanyak 2.000, C-LSTM sudah dapat memiliki kinerja (nilai F1-score) yang cukup baik. Akan tetapi, penambahan jumlah dokumen latih sampai dengan 5.000 masih memberikan peningkatan kinerja (nilai $F 1$-score) pada CLSTM sampai dengan $6,02 \%$.

\section{REFERENSI}

[1] K. Kowsari, K.J. Meimandi, M. Heidarysafa, S. Mendu, L. Barnes, dan D. Brown, "Text Classification Algorithms: A Survey," Inf., Vol. 10, No. 4, hal. 1-68, 2019.

[2] J. Li, Y. Xu, dan H. Shi, "Bidirectional LSTM with Hierarchical Attention for Text Classification," Proc. 2019 IEEE 4th Adv. Inf. Technol. Electron. Autom. Control Conf. (IAEAC 2019), 2019, hal. 456-459.

[3] M.A. Ramdhani, D.S. Maylawati, dan T. Mantoro, "Indonesian News Classification Using Convolutional Neural Network," Indones. J. Electr. Eng. Comput. Sci., Vol. 19, No. 2, hal. 1000-1009, 2020.

[4] M. Shi, K. Wang, dan C. Li, "A C-LSTM with Word Embedding Mode for News Text Classification," Proc. - 18th IEEE/ACIS Int. Conf. Comput. Inf. Sci. (ICIS 2019), 2019, hal. 253-257.

[5] C. Li, G. Zhan, dan Z. Li, "News Text Classification Based on Improved Bi-LSTM-CNN," Proc. - 9th Int. Conf. Inf. Technol. Med. Educ. (ITME 2018), 2018, hal. 890-893.

[6] A. Kulkarni dan A. Shivananda, "Deep Learning for NLP," dalam
Natural Language Processing Recipes, New York, AS: Apress, 2019, Ch. 6, hal. 185-227.

[7] P. Zhou, Z. Qi, S. Zheng, J. Xu, H. Bao, dan B. Xu, "Text Classification Improved by Integrating Bidirectional LSTM with Two-dimensional Max Pooling," Proc. COLING 2016 - 26th Int. Conf. Comput. Linguist. Tech. Pap., 2016, hal. 3485-3495.

[8] F. Zhu, X. Dong, R. Song, Y. Hong, dan Q. Zhu, “A Multiple Learning Model Based Voting System for News Headline Classification," dalam Natural Language Processing and Chinese Computing (NLPCC 2017), Lecture Notes in Computer Science, Vol. 10619, X. Huang, J. Jiang, D. Zhao, Y. Feng, dan Yu Hong, Eds., Cham, Swiss: Springer, 2018, hal 797-806.

[9] I. Goodfellow, Y. Bengio, dan A. Courville, Deep Learning, Cambridge, AS: The MIT Press, 2016.

[10] L. Yang dan A. Shami, "On Hyperparameter Optimization of Machine Learning Algorithms: Theory and Practice," Neurocomput., Vol. 415, hal. 295-316, 2020.

[11] Suyanto, "Ukuran Evaluasi Model Klasifikasi," dalam Machine Learning Tingkat Dasar dan Lanjut, Bandung, Indonesia: INFORMATIKA, 2018, hal. 334 .

[12] I. Kandel dan M. Castelli, "The Effect of Batch Size on the Generalizability of the Convolutional Neural Networks on a Histopathology Dataset," ICT Express, Vol. 6, No. 4, hal. 312-315, 2020.

[13] P.M. Radiuk, "Impact of Training Set Batch Size on the Performance of Convolutional Neural Networks for Diverse Datasets," Inf. Technol. Manag. Sci., Vol. 20, No. 1, hal. 20-24, 2018. 